\title{
THE VALIDITY OF ISLAMIC BALANCES OF REGIONAL REGULATION (PERDA) IN INDONESIA'S CONSTITUTIONAL PERSPECTIVE: \\ Indonesian Political Law to the Post Amendment Constitution of Republic of Indonesia of 1945
}

\author{
Waspada \\ Law Faculty, Bosowa University Makassar \\ wsanting_mksr@yahoo.com
}

\begin{abstract}
Islamic-based laws have a strong historical roots in Indonesia society. Culturally-based rules of Islam always flourish accompanying the history of nation's journey intertwined with the dynamics of community life. Those historical values are embodied in such a firm and clear in the philosophy and principles of the country: Pancasila and the 1945 Constitution. Therefore, the establishment, construction, and development of Islamic-based Regulations, has a constitutional foundation for formal law as enacted, either at the national or regional law order.
\end{abstract}

Keywords:

Perda based on Islam, Constitution, Political Law

\begin{abstract}
Abstrak
Hukum berbasis Islam memiliki akar sejarah yang kuat dalam masyarakat Indonesia. Aturan-aturan Islam berbasis budaya selalu berkembang menyertai sejarah perjalanan bangsa yang terkait dengan dinamika kehidupan masyarakat. Nilai-nilai historis tersebut diwujudkan sedemikian tegas dan jelas dalam filosofi dan prinsip negara: Pancasila dan UUD 1945. Oleh karena itu, pembentukan, konstruksi, dan pengembangan Peraturan berbasis Islam, memiliki landasan konstitusional untuk hukum formal seperti yang ditetapkan, baik atas perintah hukum nasional atau regional.
\end{abstract}

Kata Kunci:

Perda berdasarkan Islam, Konstitusi, Hukum Politik

\section{A. INTRODUCTION}

7 he Founding Father of the Indonesian people has established a state commitment that the Republic of Indonesia is a state based on law, not a state based on power. The national commitment is enshrined in the country's 
constitution: the Basic Law was passed on August 18, 1945. ${ }^{1}$

Based on that national commitment, the statutory regulations compiled and enforced by the state officials, must always refer to the $1945^{2}$ This commitment reinforces the noble ideals of Indonesian people. ${ }^{3}$ It is on this basis that Indonesian legal politics is formed, fostered, and developed, both at the level of objectives and in its formation.

The history of the process of forming, fostering, and developing the structure of Indonesian laws and regulations, always goes hand in hand with the aspirations of the people who want a rule of law that is accommodative to values derived from the values of religious teachings including the teachings of Islam. ${ }^{4}$

The Reformation Era was the momentum to reawaken the spirit of formalizing Islamic teachings, constitutionally in the Indonesian legal order. The Reformation Era referred to the movements carried out by various elements of the Indonesian people who were successful in forcing Soeharto to resign as President of Indonesia on the May 21st, 1998. The reform movement opened a wide door for the tajdid (renewal) process of the constitutional order which was inconsistent with developments and tended to be authoritarian, towards a more conducive order because it was based on people's aspirations. It was this accumulation of strong waves of popular aspirations that prompted the People's Consultative Assembly (MPR) for the 1999-2004 periods to amend the $1945 .^{5}$

Amendments to the 1945 Constitution brought 'perfection' to the basic rules in the process of administering the state to become more democratic. Improvements include, among other things, firmer distribution of power in tighter and more transparent checks and balances. An important change related to checks and balances is the provision of Article 5 paragraph (1) of the 1945 Constitution which initially reads: The President holds the power to form laws with the approval of the DPR, changed to: The President has the right to submit a bill to the DPR.

Kedudukan dan peranan DPR sebagai lembaga legislatif dan pemegang kekuasaan legislasi, semakin teguh. Kewenangan legislasi nasional yang semula "dimonopoli" oleh lembaga kepresidenan, kembali ke dalam genggaman rakyat, melalui wakil-wakilnya di DPR. Kendati presiden, baik sebagai kepala negara

\footnotetext{
${ }^{1}$ Safroeddin Bahar Dkk (Pen.) Risalah Sidang Badan Penyelidik Usaha-Usaha Persiapan Kemerdekaan Indonesia (BPUKPI) Panitia Persiapan Kemerdekaan Indonesia (PPKI) 28 Mei-22 Agustus 1945. (Jakarta: Sekretariat Negara Republik Indonesia, 1995), p. 161.; A.B. Kusuma, Lahirnya Undang-undang Dasar 1945. Edisi Revisi (Jakarta: Badan Penerbit Universitas Indonesia, 2009), p. X

${ }^{2}$ Imam Syaukani dan A. Ahsin Thohari, Dasar-dasar Politik Hukum (Jakarta: Raja Grafindo Persada, 2004), p. 65. 152.

${ }_{3}^{3}$ Satjipto Raharjo, Sisi-sisi Lain dari Hukum di Indonesia (Jakarta: Kompas Media Nusantara, 2006), p.

${ }^{4}$ Hamdan Zoelva, "Syari'at Islam dan Politik Hukum Nasional Indonesia", dalam http:// hamdan zoelva. wordpress.com/2008/04/01/syari\%E2\%80\%99at-islam-dan-politik-hukum-nasional -indonesia/. Diakses Jumat 11 Mei 2019, 04: 55 WITA.

5 Pataniari Siahaan, Politik Hukum Pembentukan Undang-undang Pasca Amandemen UUD 1945. (Jakarta: Konstitusi Press, 2012), p. 254.
} 
maupun sebagai kepala pemerintahan tetap memegang kekuasaan menjalankan UU, tetapi dalam proses pembahasan dan penetapan UU memiliki kewenangan yang sama dengan DPR. Pasal 20 ayat (2).

The position and role of the DPR (House of Representatives) as a legislative body and the holder of legislative power, are becoming more firm. The authority of national legislation which was originally 'monopolized' by the presidential institution, returned to the hands of the people, through its representatives in the DPR. Even though the president, both as head of state and as head of government, still holds the power to run the law, but in the process of discussion and enactment of the law has the same authority as the DPR. Article 20 paragraph (2).

The more proportional sovereignty of the people in the process of forming new laws as well as changes, fostering, and developing old laws, has positive implications in national legislation. National legal politics accommodate more aspirations of Muslims in every legal product, both the Law that was born based on the initiative of the people's representatives, and the Bill based on the proposal of the executive.

Changes in national legal politics became a new encouragement for Muslims in pushing for the formation of new laws with high Islamic ideals. Aspirations of Muslims in legislation, marked by the ratification of a number of independent Islamic-based laws, including: RI Law No. 38 of 1999 concerning Management of Zakat; RI Law No. 41 of 2004 concerning Endowments along with Government Regulation (PP) No. 42 of 2006 concerning the Implementation of RI Law No. 41 of 2004 concerning Endowments; RI Law No. 13 of 2008 concerning Implementation of Hajj; and RI Law No. 21 of 2008 concerning Sharia Banking. The latest RI Law No. 33 of 2014 concerning Halal Product Guarantee (JPH). In the local context, the formation and enactment of RI Law No. 22 of 1999 concerning Regional Government aroused the enthusiasm of Muslim communities in various regions to urge the government in their regions to accommodate Islamic values in Regional Regulations (Perda).

Islamic-based laws and regulations, including regional regulations in various regions, have received studies from various groups. Haedar Nashir (2007) refers to the struggle of the Muslim community in regional legislation as the bottom line islamization. ${ }^{6}$ The formalization of Islamic values in civil law often creates a conflict of values, so that it requires a serious review in the process of forming national law. ${ }^{7}$ Bustanul Arifin (1996). In fact, the struggle for the formalization of Islamic law in Indonesia is a struggle that has never been completed in the era of regional autonomy, especially with regard to the dynamics of thought and aspirations of Muslims in the field of family law, economics, and various economic disputes. ${ }^{8}$ The dynamics of struggle cannot be separated from the political configuration of national

\footnotetext{
${ }^{6}$ Haedar Nashir, Gerakan Islam Syari'at: Reproduksi Salafiyah Ideologis di Indonesia (Jakarta: Pusat Studi Agma dan Peradaban/PSAP Muhammadiyah, 2007), p. 606.

${ }^{7}$ Busthanul Arifin, Pelembagaan Hukum Islam di Indonesia: Akar Sejarah, Hambatan, dan Prospeknya (Jakarta: Gema Insani Perss, 1996), p. 33-37

${ }^{8}$ Mustafa dan Abdul Wahid, Hukum Islam Kontemporer (Jakarta: Sinar Grafika, 2009), p. 75-83
} 
law, especially in the process of actualizing the causal relationship between law and politics in the reform era. ${ }^{9}$

Related to the dynamics of legal politics in the process of struggling to formalize Islamic values, it has led to the ratification and enactment of Islamic based regulations in a number of regions, which has led to pro and contra stances. The support of the majority of Muslims cannot deny the attitudes of small groups who openly reject the enactment of the Perda, and do not even hesitate to gather power to overturn it.

This paper examines the validity of the formation, formation, development and application of Islamic-based regional regulations in the perspective of the national constitution: the 1945 Constitution.

\section{B. DISCUSSION}

\section{Regional Regulations Position in the National Legal System}

The fall of the government of the new order regime which was replaced with a reform government, showed an increase in the performance of legislation, especially in the formation of legislation, both in quality and quantity. This is one of the tangible results of the amendment to the 1945 Constitution. The results of the mandement have pushed the process of drafting legislation (PUU) with an increasingly orderly, directed and measurable mechanism.

Article 18 paragraph (6) of the 1945 Constitution states that "Regional Governments have the right to stipulate Regional Regulations and other regulations to carry out autonomy and assistance tasks". This confirms that the Perda as a national PUU, has a strong constitutional and juridical foundation. The national legal system gives attributive authority to regions to enact regulations and other regulations. The presence of the Regional Regulation, of course, is expected to be able to support synergistically the Government's programs in the regions.

Perda as one of the rules in the hierarchy of the rules and regulations is formed by the Regional House of Representatives with the agreement of the Regional Head (governor or regent / mayor). The mention of the Perda differs in certain regions, based on the specifics of the area. Qanun is a term for a law in Aceh. Whereas in Papua Province it is called a special regulation.

The constitutionality of Perda is emphasized legally in Article 14 of Law Number 12 of 2011 that, Perda must contain arrangements regarding the implementation of regional autonomy, co-administering tasks, and accommodating the special conditions of the region and or further elaboration of the higher PUU. The draft Perda (Raperda) can come from

\footnotetext{
${ }^{9}$ Mahfudh MD, Politik Hukum di Indonesia. Edisi Revisi (Jakarta: RajaGrafindo Persada, 2011), p. 1
} 
the DPRD or the Regional Head, and then it is discussed to obtain mutual agreement to be ratified as a Perda.

The transfer of some authority from the central government to the regional government has placed the regional government as the spearhead of national development in an effort to create prosperity for the people in a fair and equitable manner. The role and support of the region in the implementation of PUU has become very strategic, especially in making regional regulations and other regulations in accordance with regional needs, while still referring to the provisions of the legislation.

Article 7 paragraph (1) RI Law No. 12 of 2011 stipulates PUU type and hierarchy consisting of: 1945 Constitution of the Republic of Indonesia, Republic of Indonesia Decree; Law / PP Substitute for Law; PP; Perpres; Provincial Regulations; and Regency / City Regulations. Even though in the order of PUU, the Perda is in the 'carried away' sequence, but its existence has a strategic function in realizing legal certainty. The legal certainty function of PUU must fulfill certain requirements, among others, consistent in the formulation in which the same PUU must maintain a systematic relationship between its rules, structure and language, and the existence of harmonization between various statutory regulations.

The harmonization of PUU has urgency in relation to the principle that lower legislation must not conflict with higher legislation, so that what is fundamental in drafting regional regulations is the suitability and synchronization with other PUUs.

Changes in legal politics accompanied by the passing of Regional Autonomy which began with the formation of RI Law No. 22 of 1999 concerning Regional Government aroused the enthusiasm of the community to encourage the formation of various regulations to fulfill their civil legal rights at the local level. Muslim communities also take advantage of this momentum by submitting aspirations to their local governments to accommodate Islamic teachings in the local legal order. This aspiration received positive appreciation from the government in various regions. Within a period of 20 years after the reformation, there were recorded at least 181 Perda or Regulations Governor (Pergub) and Regents Regents (Perbup) nuanced Islamic Sharia throughout Indonesia. ${ }^{10}$

Even though Islamic-based regional regulations, governing regulations, and district regulations / regulations are limited to issues related to worship and a small part of mu'amalah, these conditions have become a new nursery for the application of formal-legalistic Islamic-based law in the lives of Indonesian Muslim communities. This reality reinforces that the democratic process that occurs is based on the rule of law, and slowly and surely, denies the authoritarian system of government which is dominated by the spirit of the rule of man. ${ }^{11}$

\footnotetext{
${ }^{10}$ Haedar Nashir, Gerakan Islam Syari'at: Reproduksi Salafiyah Ideologis di Indonesia, p. 606.

${ }^{11}$ Jazim Hamidi dan Malik, Hukum Perbandingan Konstitusi (Jakarta: Prestasi Pustaka, 2008), p. 1.
} 


\section{The validity of Islamic-based law in Indonesia}

The ulama of ushul 'agreed' three principles in the process of applying or implementing Islamic law, namely: not burdensome or not narrowed, did not increase the burden or demand, and carried out gradually. ${ }^{12}$ Islamic teachings are not burdensome because their implementation is adjusted to the objective abilities of everyone. ${ }^{13}$ This confirms that Allah SWT that, does not want any difficulties for everyone in trying to carry out religious teachings (Q.S. Al-Hajj / 22: 78). ${ }^{14}$ In fact, Allah precisely wants an ease and does not want any difficulties to (QS. Al-Baqarah / 2: 286$){ }^{15}$

This stipulation confirms that in evaluating every act of a moslem as servant and his obedience to the provisions Allah swt. always focusing on factors istitha'ah (ability). A preacher who is objectively unable to fulfill an order, is 'free' from obligation and free from responsibility. Based on that principle,within the ushul fiqh was born the provisions about rukhsah as an alternative way to facilitate people who have difficulty in implementing shariah law. ${ }^{16}$

Religion is revealed to bring benefit for humans. Naturally, the commands and prohibitions do not burden people and do not cause difficulties. Because, one aspect of the benefit is make things easier. Obedience to God's laws will free people from things that damage and harm their lives.

Islam also does not impose burdens on humans that exceed the limits of reasonableness and objective abilities that are consistent with their human nature (Surah Al-Baqarah / 2: 286). ${ }^{17}$ Allah SWT. invites humans to think about the process of its occurrence as a creature of His creation. As a Creator, Allah surely knows in detail the maximum ability that exists in every Muslim to carry out all of Allah's commands while avoiding all His prohibitions. Logically, it is impossible for Allah to reduce commands that are impossible for humans to do, just as God cannot forbid an action if it does not have a negative impact on those who do it. ${ }^{18}$

Determination of Islamic teachings carried out in stages, shown through the stages of the revelation of the Quran. Revelation gradually brings wisdom, in addition to " making it easier " Rasulullah saw. together with his friends to solidify his reading, also in order to make the content of the Quran more easily lived and practiced in accordance with the peak of perfection. The process allows everyone to maximize their potential thinking and zikir in choosing: taking benefits for the greater good or mudharat with their respective consequences. Upholding the

\footnotetext{
${ }^{12}$ Hamka Haq, Falsafah Hukum Islam (Makassar: Yayasan Al-Ahkam, 1998), p. 54.

${ }^{13}$ Zainuddin Ali, Hukum Islam: Pengantar Hukum Islam di Indonesia (Jakarta: Sinar Grafika, 2006), p. 49.

${ }^{14}$ Kementerian Agama RI, Alqur'an dan Terjemahnya (Edisi yang Disempurnakan). Jilid VI, (Jakarta: Direktorat Bimbingan Masyarakat Islam, 1912), p. 459

${ }^{15}$ Kementerian Agama RI, Alqur'an dan Terjemahnya (Edisi yang Disempurnakan), Jilid I, p. 439

${ }^{16}$ A. Hanafie, Usul Fiqh (Jakarta: Widjaya, 1981), p. 15.

${ }^{17}$ Kementerian Agama RI, Alqur'an dan Terjemahnya (Edisi yang Disempurnakan), Jilid I, p. 439.

${ }^{18}$ Waspada Santing, Profesi Jurnalistik Perspektif Hukum Islam (Makassar-Jogyakarta, 2017), p. 66
} 
teachings of religion will have maximum implications with the application of the consequences.$^{19}$

The institutionalization of Islamic based laws and regulations in the process of forming, fostering, and developing national law in Indonesia has gone through a long history; beyond the age of independence of the Republic of Indonesia. Various records of experts and interested in the history of law in Indonesia said that the institutionalization process began since the teachings of Islam entered and became the belief of the people in various regions of Indonesia, before the Dutch colonial period and continues to this day. The development of thought and related studies with the institutionalization of Islamic-based law in Indonesia, has given birth to several theories, namely:

\section{a. Legal Obedience Theory.}

By the condition of law in society, automatically applies the principle 'for Muslims to apply Islamic law'. Before the Dutch entered the archipelago, Islam had a significant influence in Indonesian society; influence the behavior of the law and the legal system of society. The royal government and the sultanates in several regions made Islamic-based legal norms as a reference in the lives of their people. Al-Ahkam al-Sulthaniyah's book, for example, has a very strong influence in shaping understanding and experience in the field of state administration in the people of Aceh. This book is used by the Sultanate of Aceh to form social life units by 'adopting' a tasyrik and taklif system. Based on the theory of legal compliance, a Muslim is ordered to obey Islamic law, even if he lives in a non-Islamic society or country. Legal observance is not dependent on the form of a Muslim society or an Islamic state. ${ }^{20}$

The Qur'anic teaching emphasizes that the adherence to Islamic law depends on the awareness of the law, the moral aspirations, and the strength of a believer's belief in Islamic teachings. Taking other legal options outside the purview of God and His Messenger is unjust, infidel, and corrupt Q.S. Al-Maidah (5): 44, 45, 47). ${ }^{21}$ So conceptually, the principles of Islamic teaching include the application and compliance of Islamic law to Muslims. Islam requires every believer to obey Islamic law. In fact, the level of faith of a mukallaf is determined by its adherence to his/her compliance and obedience to Islamic law.

Commandments in the Qur'anic verses for believers to obey and compliance to ulil amri accompany their obedience to Allah Almighty. and Allah's Messenger (may peace be upon him), illustrates the urgency of the adherence of the Muslims to the legal formula formulated through the process of Islamic jurisprudence in addressing the challenges of the people's lives amidst the current of change, modernization and civilization.

\footnotetext{
${ }^{19}$ Hazairin, Tujuh Serangkai Tentang Hukum (Jakarta: Bina Aksara, 1981), p. 13.

${ }^{20}$ Ichtijanto, Hukum Islam dan Hukum Nasional (Jakarta: Indo-Hill Co, 1990), p. 23.

${ }^{21}$ Kementerian Agama RI, Alquran dan Terjemahnya (Edisi yang Disempurnakan), Jilid II, p. 403-404
} 
Thus, for Muslims, being loyal and obeying the rules of Allah swt., The Messenger of Allah (may peace be upon him), and his followers are part of believing the law. Implementing Islamic law is the goal of his life to achieve happiness, peace, and happiness in life, as well as eternal salvation in the hereafter in accordance with Islamic law-based goals.

\section{b. The theory of Law Otority Acceptance}

This theory was popularized by HAR Gib who saw that, someone who had accepted Islam as his belief, basically accepted the authority of Islamic law over him. People who are already Muslim, sociologically accept the authority of Islamic law, so that they obey Islamic law. The level of observance of a Muslim differs according to the degree of his devotion to Allah. People who have embraced Islam, members of the community also justify the " power " of Islamic law. Islamic law exists in society because it is obeyed by Muslims. People who have accepted Islam as their religion mean accepting the authority of Islamic law over themselves. For them, Islamic law is the will and order of Allah and the traditions of His Messenger. ${ }^{22}$

\section{c. Theory of Receptie in Complexu.}

This theory was put forward by Prof. Mr. Lodewijk Willem Christian van den Berg (1845-1927), advisor to the Dutch government in Indonesia in the field of law. Van den Berg, an expert on Islamic law and referred to as the " inventor and initiator of the implementation of Islamic law in Indonesia ", although in fact many writers have talked about it before. Van den Berg saw the legal politics of the Dutch Indian government and the legal realities in Indonesia, so that it emphasized that the prevailing and ongoing legal politics and formulating rules for the enactment of Islamic law by saying that: "For indigenous people, it applies to their religious law ". The formula was published in Staatblad (stbl) 1882 No. 152 and called the theory of Receptio In Complexu. This theory confirms that the law that applies to a case is according to the religion of the people in the area.

Van den Berg, who lived in Indonesia for 17 years (1870-1887), was also the initiator of the implementation of Islamic law and Islamic marriage law by Dutch judges in the Indonesian Court, with the help of Islamic leaders and cadres. It also served to provide a better understanding of Dutch officials and Dutch judges on Islamic law. Van den Berg wrote Mohammadanch Recht (Fundamentals of Islamic Law) in the perspective of Imam Shafi'i and Hanafi (1882). It also translates the books of Fathu al-Qariib and Minhaaj al-Thalibin from Arabic. ${ }^{23}$

Van den Berg's initiative triggered the theory of Receptio In Comlekxu, which had played a major role in the application of Islamic law in Indonesia, even though at that time it only applied to religious and colonial adherents. Exit Stbl. 1882152 stipulates that the judiciary, which existed before the Netherlands Indies government

\footnotetext{
${ }^{22}$ Ichtijanto, Hukum Islam dan Hukum Nasional, p. 24.

${ }^{23}$ Sayuti Thalib, Receptie A Contrario (Jakarta: Bina Aksara, 1982), p. 15-17.
} 
in Indonesia, continue and recognize its legal authority. This recognition justifies the legitimacy of the judicial process carried out by cadres in traditional justice institutions.

\section{d. Receptie Theory}

This theory was coined by Christian Snouck Hurgoronye (1857-1936), then developed by Christian van Vollenhoven and Ter Haar Bzn. Snouck Hurgronye advises the Dutch government on Islam. To deepen his knowledge of Islam, in 18841885, about seven months Snouch deepened his knowledge of Islam in Mecca, disguised as an ophthalmologist and photographer named Abdul Gaffar. Snouck's idea in Receptie's theory departed from his desire to weaken the determination of native peoples of the colonies to comply with Islamic teachings. He considered, Muslims who firmly uphold the teachings of their religion, are not easily influenced by Western civilization. In addition, he is worried that the spirit of Pan Islamism Jamaluddin Al-Afghani is influential in Indonesia.

Snouck gave advice to the Dutch government that in the order of social life respecting the customs of the community, but in the state administration prevents goals that can connect the Indonesian Muslim community with the influence of Pan Islamism. Based on that advice the Dutch government decided that, " Islamic law only applies if it is accepted by the community as its custom '. The decision was contained in Article 134 of the Indische Staatsregeling (IS) paragraph (2) which is known as the receptie article.

Receptie's theory is anti-thesis of the theory of Receptio In Complexu, which was invented by Van den Berg. The point is that, for the indigenous Muslim community, the applicable law is not Islamic law, but its customs. Islamic law may only function and be enforced if it has been accepted by the community as part of its custom. Based on the receptie article, the Dutch East Indies government paralyzed the implementation of Islamic law in Indonesia. ${ }^{24}$

\section{e. Receptie Exit Theory}

The Receptie Exit Theory was coined by Prof. Hazarin, SH. According to him, after Indonesia's independence and the 1945 Constitution was made a State Law, even though Article 1 of the Transitional Rules of the 1945 Constitution was stated: "All existing laws and regulations are still in force before a new one is held", but the receptie theory must exit from the Indonesian land. Besides not in accordance with the spirit of the 1945 Constitution, it is also very contrary to the Qur'an and the Sunnah of the Prophet. Hazairin even called the receptie theory the devil's theory. Following the logic of receptie theory only makes Indonesian Muslims be divided until tips day. For Hazairin, the basis for the enactment of Islamic law and other religions is article 29 verse (1): " The State is based on a One GodOne God ". This article becomes a legal line containing obligations for the state to make Indonesian

\footnotetext{
${ }^{24}$ Hazairin, Tujuh Serangkai Tentang Hukum, p. 58-70.
} 
National Law which is based on religious law based on Divine revelation. The 1945 Constitution has ended the adoption of receptie theory, so that it must exit from Indonesian state administration. ${ }^{25}$

\section{f. Receptie a Contrario.}

Through the book, Receptio A Contrario: The Relationship between Customary Law and Islamic Law Sayuti Thalib stated that, in the reality of Indonesian society, Islamic law applies to Muslims. That is according to the beliefs, inner voice, and moral ideals of Muslims. Customary law for Indonesian Muslims, can only be enforced if it does not conflict with Islam and Islamic law. This theory is called Receptio A Contrario because it contains a view that is the opposite of the Receptie theory that was coined by Snouck Hurgronye. Sayuti Thalib stressed her stand that, based on the Pancasila and the 1945 Constitution, religious people have a basis to freely practice their religious teachings and obey their religious laws. The principle 'for Muslims applies Islamic law', should be a moral ideal and legal awareness in society. Thus, for Indonesian Muslims, norms and customs that conflict with Pancasila, the 1945 Constitution, and Islamic law, should not be given the opportunity to live and be enforced in Indonesia.

\section{g. Theory of Existence.}

This theory was put forward by Ichtijanto, who explained the existence of Islamic law in national law. There are, as an integral part of national law; the independence and power of authority of Islamic-based law are recognized and given status as national law; Islamic legal norms function as filters for national legal materials; as well as the main ingredients and main elements of Indonesian National law. Some of Ichtijanto's arguments are the background and proof of his theory, including: the national consensus of 22 June 1945 regarding the basic formulation of the state in the Pancasila; The 1945 Constitution provides impetus for the function of religious law, in this case Islamic law; the spirit of the people in various regions who want to rule with Islamic law is very strong; as well as moral ideals, inner ideals, mental atmosphere, and character of the Indonesian people.

Ichtijanto's argument confirms that in the practice of law, the practice of state administration, and social relations of people in Indonesia, Islamic law occupies a very strategic position. Obedience to Islamic law in the life of state administration within certain limits - is evidence of the existence of Islamic legal authority in Indonesian national law. ${ }^{26}$

In addition to some of these theories, it is interesting to ponder the 'objectivity theory' of Islamic teachings in the order of life of the Indonesian people from Kuntowijoyo. In this perspective, the process of thought, action and practice of Islamic teachings by Indonesian Muslims takes place naturally. The naturalization

${ }^{25}$ Sayuti Thalib, Receptio A Contrario: Hubungan Hukum Adat dengan Hukum Islam (Jakarta: Bina Aksara, 1980), p. 15-70.

${ }^{26}$ Ichtijanto, Hukum Islam dan Hukum Nasional, p. 86-87. 
process minimizes the 'conflict' between cultural values in society and religious norms, because the practice and obedience that they produce are based on religious awareness that grows from within the community itself. ${ }^{27}$

Although Kuntowijoyo's view is not popular in the study of Islamic law, however, objectification leads to the naturalization of the concepts and dimensions of Islamic law that may be 'risky' if applied arbitrarily, both in of the context of the terms and its legal material. The objectification process of Islamic law terminology will get rid of the attitude of Islamic Phobia (Muslims who are allergic to the teachings of their own religion), so that there is no impression of the dominance of one religious community over other religious communities that happen to be minorities. The term of Islamic law is not being used, so what appears is a general and natural term, so as if it is not from Islam, but the material is very Islamic.

Based on various views on the process of institutionalizing Islamic-based law in national law, it can be said that in the practice of Indonesian law and state administration practices, it is built and fostered on three pillars, namely Islamic law, customary law and Western law. In this context, the 'objectification' approach in the process of national legal regulation is very relevant to be an alternative, so that the existence of Islamic-based law becomes more robust and becomes part of the dominance of customary law and Western law.

The power of " attraction " in the three pillars in the development of national law, always causes debate. In fact, it is not common to lead to conflict and collision. That kind of condition has been going on for a long time, since the Dutch East Indies colonial period, especially after the theory of Receptie Snoch Hurgronye was established as an organic rule by the Dutch East Indies government in Indonesia. However, debate, conflict and clash did not reduce the spirit to fight for the institutionalization of Islamic-based law in national law, in various variants.

Various legal theories about the validity of Islamic-based law in Indonesia, which were coined based on the results of a number of legal experts throughout the history of the Republic of Indonesia, show how Islamic-based law has strong historical roots. Its strength is congruent with the historical foundation which gave birth to the philosophy and fundamentals that became the basis of the existence ofIndonesia.

\section{Position of Islamic Based Regulations in the Republic of Indonesia's Constitution: 1945 Constitution}

The government cycle after the amendment to the 1945 Constitution, led to demands from the community to set a firmer boundary between popular sovereignty and state authority. The separation and division between the representation of the people through the legislature and the power of the State represented by the

27 Kuntowijoyo, "Agama dan Demokrasi di Indonesia" dalam Demokrasi Indonesia Kontemporer (Jakarta: Raja Grapindo Persada, 1996), p. 26-38. 
government, is becoming increasingly clear. The basic rights of citizens, the freedom of individuals and groups, are protected in an orderly and measured manner. The authority, structure of government, and the process of accountability of the authorities to the people, is set forth in the form of social and political contracts which in the constitutional system are called constitutions. ${ }^{28}$

The highest social agreement forms making the constitution as a source of fundamental law and a source of legitimacy for the basis of authorization for all variants of the law and legislation.. The substance of the constitution is the crystallization of noble values that live, grow and develop in the history of national civilization. ${ }^{29}$ Thus, the constitution always contains the ideals to be achieved by the formation of a State, as well as the basic principles in the process for achieving those goals. ${ }^{30}$ This brings the idea of living constitution which means that the constitution is not just a written rule, but also includes the constitutional conventio ${ }^{31}$. The 1945 Constitution adheres to this under-standing. ${ }^{32}$

This perspective is a strong justification that the application of religion-based law, especially, of course, Islamic law is a necessity of the constitution. Because Islamic-based law has grown and developed in the order of life of Muslims in the archipelago for centuries. Islamic-based law in various variants has been applied by the Indonesian Muslim community for hundreds of years, before independence was proclaimed.

In addition, although the sentence with the obligation to carry out Islamic sharia for its adherents was removed - meeting the needs of national unity and integrity - from the Jakarta Charter prepared by BPUPKI as a preamble to the 1945 Constitution, the enthusiasm for Islamic-based law enforcement remained embodied in the sentence of the Believe in One God Almighty. ${ }^{33}$ For Ki Bagus Hadikusumo, said the Almighty after the word Believe in God, is worth of monotheism. It was this consideration that motivated Ki Bagus to propose the three words to replace the seven words that were omitted from the Jakarta Charter text on the 'initiative' 'Muhammad Hatta. ${ }^{34}$

\footnotetext{
${ }^{28}$ Jimly Ashshiddiqie, Konstitusi dan Konstitusionalisme Indonesia, (Jakarta: Sinar Grafika, 2010), p. 29.

${ }^{29}$ Masdar Farid Mas'udi, Syarah Konstitusi UUD 1945 dalam Perspektif Islam (Jakarta: Pustaka AlvabetLakif, 2010), p. 4

${ }^{30}$ Rofiqul-Umam Ahmad dkk (ed.), Konstitusi dan Ketatatanegaraan Indonesia Kontemporer: Pemikiran Jimly Asshiddiqie dan Para Pakar Hukum (Jakarta: The Biography Institute, 2007), p. 11.

${ }^{31}$ Miriam Budiardjo, Dasar-dasar Ilmu Politik (Jakarta: Gramedia, 1977), p. 103.

${ }^{32}$ Irfan Idris, Islam dan Konstitusionalisme: Kontribusi Islam dalam Penyusunan Undang-undang Dasar Indonesia Modern (Yogyakarta: AntonyLib, 2009), p. 3.

${ }^{33}$ Endang Syaifuddin Anshari, Piagam Jakarta 22 Juni 1945: Sebuah Konsensus Nasional Tentang Dasar Negara Republik Indonesia (1945-1949), Edisi Ketiga (Jakarta: Gema Insani Press, 1997), p. 47.

34 Muhammad Yamin, Naskah Persiapan Undang-Undang Dasar 1945 (Jakara: Yayasan Prapanca, 1959), p. 410; Muhammad Yamin, Pembahasan Undang-undang Dasar Republik Indonesia (Jakarta: t.p., t.th.), p. 11.
} 
The value of believing in The Almighty God can only stays on mind and become the wisdom of Indonesians who believe in Islam. ${ }^{35}$ It is the Almighty God which is listed in the fourth paragraph of the Preamble of the 1945 Constitution. That sentence is also stated in the first principle of the Pancasila and agreed upon as the philosophy and basis of the state. The constitutionality of the sentence with the value of monotheism is getting stronger after the amendment of the 1945 Constitution.

Amendments to the 1945 Constitution which occurred four times in the period 1999-2002, have never disturbed issues related to religious articles. In fact, the Almighty God is increasingly strengthened and improved. Not only listed in Article 29 paragraph (1) and paragraph (2) of the 1945 Constitution, but also stipulated as one of the most fundamental rights for every citizen in a special Chapter on Human Rights (HAM). The right to religion and freedom to practice the teachings of every religious community, including Muslims, are included in Article 28E paragraph (1) and paragraph (2) of the 1945 Constitution based on the results of the fourth amendment Indonesian Constitutional Court of the Republic of Indonesia. ${ }^{36}$

Open space in the State's constitution, as well as the juridical basis in various laws and regulations, as well as a conducive atmosphere for the process of formulating various forms of new Islamic-based legal variants, and their implementation in the governance of Muslim societies in Indonesia, must not be disturbed by any group of people simply because they are not pleased with the formalization of Islamic-based law.

The formalization of Islamic-based law in various laws and regulations is carried out in a constitutional manner. Its formulation, discussion, and endorsement also rolled through a difficult process based on juridical rules in the legislature. If there are parties who are not happy with the existence and enforcement of Islamic based laws and regulations and want to overcome them, they must go through a channel based on juridical basis. Rejecting an Islamic-based legal order can be viewed as a rejection of the constitutional mandate.

\section{CONCLUSION}

Regional Regulation (Perda) is one form of legislation that has a constitutional basis. The content material regulates the implementation of regional autonomy, coadministration tasks, accommodating regional conditions or further extension of the higher statutory regulations.

Islamic-based Regional Regulations (Perda) that are formed (compiled, discussed, then ratified) based on the legislative process established in the rules for

${ }^{35}$ Hazairin, Demokrasi Indonesia (Jakarta: Tintamas, 1970), p. 58.

${ }^{36}$ Mahkamah Konstitusi Republik Indonesia, Naskah Komprehensif Perubahan Undang-Undang Dasar Negara Republik Indonesia: Buku VIII Warga Negara dan Penduduk, Hak-hak Asasi Manusia, dan Agama (edisi Revisi Sekretaris Jenderal dan Kepaniteraan Mahkamah Konstitusi, 2010), p. 359. 
the formation of laws and regulations, have constitutional validity to be implemented.

Refusing the application of Islamic-based regulations can be seen as a rejection of the provisions in the constitution.

\section{Bibliography}

Al-Qur'an al-Karim

Agama, Kementerian, RI., Al-Qur'an dan Tafsirnya., Jakarta: Direktorat Jenderal Bimbingan Masyarakat Islam, 2012.

Ahmad, Rofiqul-Umam Ahmad (ed.), Konstitusi dan Ketatatanegaraan Indonesia Kontemporer: Pemikiran Jimly Asshiddiqie dan Para Pakar Hukum. cet. I; Jakarta: The Biography Institute, 2007.

Abdillah, Masykuri., Demokrasi di Persimpangan Makna Respons Intelektual Muslim Indonesia Terhadap Konsep Demokrasi 1966-1993. Yogyakarta: Tiara Wacana, 1991.

Asshidiqie, Jimly., Konstitusi \& Konstitusionalisme Indonesia, Jakarta: Sinar Grafika, 2010

Anshari, Endang Saifuddin, Piagam Jakarta 22 Juni 1945, Jakarta: Rajawali Press, 1986.

Budiardjo, Miriam, Dasar-Dasar Ilmu Politik. Jakarta: Gramedia Pustaka Utama. 2008.

Hamidi, Jazim dan Malik, Hukum Perbandingan Konstitusi. Jakarta: Prestasi Pustaka, 2008.

Hazairin, Demokrasi Indonesia . Jakarta: Tintamas, 1970.

Haq, Hamka, Pancasila 1 Juni dan Syariat Islam, Jakarta: Baitul Muslimin, 2011.

Idris, Irfan, Islam dan Konstitusionalisme: Kontribusi Islam dalam Penyusunan UUD Indonesia Modern, Yogyakarta: AntonyLib, 2009.

Kuntowijoyo, "Agama dan Demokrasi di Indoesia" dalam Demokrasi Indonesia Kontemporer. Jakarta: RajaGrapindo Persada, 1996.

Mahkamah Konstitusi RI., Naskah Komprehensif Perubahan UUD Negara RI Tahun 1945:

Buku VIII: Warga Negara dan Penduduk, Hak Asasi manusia dan Agama, Jakarta:

Setjen dan Kepaniteraan MK RI, 2010.

Mas'udi, Masdar Farid, Syarah Konstitusi: UUD 1945 dalam Perspektif Islam, Jakarta: Alvabet - LaKIP, 2010.

Mahfud MD, Moh., Membangun Politik Hukum, Menegakkan Konstitusi, Jakarta: Rajawali Pers, 2011. 
Muhammad Yamin, Naskah Persiapan Undang-Undang Dasar 1945. Jakarta: Yayasan Prapanca, 1959.

Nashir, Haedar., Gerakan Islam Syari'at: Reproduksi Salafiyah Ideologis Indonesia. Jakarta: Pusat Studi Agama dan Peradaban Muhammadiyah, 2007.

Raharjo, Satjipto., Sisi Lain dari Hukum di Indonesia. Jakarta: Kompas Media Nusantara, 2006.

Pataniari Siahaan, Politik Hukum Pembentukan Undang-undang Pasca Amandemen UUD 1945. Cet. 1. Jakarta: Konstitusi Press, 2012.

Rofiq, Ahmad., Hukum Islam di Indonesia. Jakarta: Raja Grapindo Persada, 1995.

Sekretaris Jenderal MPR RI., Risalah Perubahan Undang-undang Dasar Negara Republik Indonesia Tahun 1945 (1999-2002) Tahun Sidang 2002, Buku Lima, Jakarta: Sekretaris Jenderal MPR RI, 2008.

Syuakani, Imam dan A. Ahsin Thohari, Dasar-dasar Politik Hukum. Jakarta: Raja Grafindo Persada, 2004.

Santing, Waspada., Profesi Jurnalistik Perspektif Hukum Islam. Makasar, Pustaka alZikra, 2012.

Tutik, Titik Triwulan, Konstruksi Tata Negara Indonesia Pasca Amandemen UUD 1945, Jakarta: Kencana, 2010.

Undang Undang Dasar Negara Kesatuan Republik Indonesia 1945

Undang-Undang RI No. 12 Tahun 2011 tentang Pembentukan Peraturan PerundangUndangan.

Yamin, M. Naskah Persiapan Undang-Undang Dasar 1945, Jakarta: Siguntang, 1959

Zoelva, Hamdan, "Syari'at Islam dan Politik Hukum Nasional Indonesia", dalam http:// hamdan-zoelva.wordpress.com/2008/04/01/syari\%E2\% 80\%99at-islam-\&politik-hukum-nasional-indonesia/. Diakses, Jumat, 11 Mei 2019, 04: 55 WITA. 